\title{
(RE)DISCOVERING A MISSIONAL-INCARNATIONAL ETHOS
}

Authors:

Jacobus Kok

Cornelius J.P. Niemandt ${ }^{2}$

\section{Affiliations: \\ ${ }^{1}$ Department of New \\ Testament Studies, \\ University of Pretoria, \\ South Africa}

${ }^{2}$ Department of Science of Religions and Missions, University of Pretoria, South Africa

\section{Correspondence to:} Cornelius J.P. Niemand

e-mail:

nelus@pixie.co.za

\section{Postal address:}

75 Elveram St, Lynnwood Glen 0081, Pretoria,

South Africa

\section{Keywords:}

ecclesiology; healing and restoration; organic movement; spirituality; transformational ethos social movement; socioreligious brokenness

\section{Dates:}

Received: 30 May 2009 Accepted: 01 Sept 2009 Published: 19 Nov. 2009

How to cite this article: Kok, J. \& Niemandt, C.J.P., 2009, '(Re)discovering a missional-incarnational ethos', HTS Teologiese Studies/Theological Studies 65(1), Art. \#274, 7 pages. DOI: $10.4102 /$ hts.v65i1.274

\section{This article is available} at: http://www.hts.org.za

(c) 2009. The Authors. Licensee: OpenJournals Publishing. This work is licensed under the Creative Commons Attribution License.

\section{ABSTRACT}

In this article, a few of the elements and dynamics of social movements will be explored. It will be argued that the traditional institutional church is in a critical period in the cycle of movements, where the need for the (re)discovery of our missional-incarnational ethos and the theology of restoration might energise the church to (re)activate the dynamics of movements. The narrative of Jesus and the Samaritan woman in John 4 will be investigated as an example of Jesus's missionalincarnational ethos and of the relation to a theology of restoration. Finally, some challenges for the church with regard to ecclesiology, spirituality and leadership will be proposed.

\section{INTRODUCTION}

Bash (1995) stated that all social change starts with the construction of alternative stories of what is possible, of an alternative reality filled with hope, expectation and possibility, and that it is often in the context of loss, crisis and disorientation that the need for alternative stories is born. Keel (2007:25) said that the story is at the heart of God's activity in the world. Frost (2006:13) called both the Jewish exiles and the Christian movement 'story-formed communities'. Recently, a number of South African pastors met with Alan Hirsch in Achterberg, South Africa, where he lectured on his recent book The forgotten ways (2006). To many of us, this facilitated a space in which the need for alternative stories for a missional church was born ( $c f$. also Keifert 2007). This article builds on the insights of Hirsch and others, such as Frost and Hirsch $(2003,2009)$, Frost (2006), Gibbs and Coffey (2001), Keel (2007) and Peterson (2008).

In the context of the church or, rather, the Jesus movement, we have to acknowledge that it is a sociological reality, with the inherent dynamics of any social movement. By exploring the dynamics of social-movements theory, the story of the church and its calling to become a missional movement might be supported, mobilised, activated and energised.

\section{EXPLORING THE DYNAMICS OF SOCIAL MOVEMENTS}

\section{From Death to Life}

Right from the beginning, the Jesus movement was not a religion, neither was it an institution - it was essentially an organic movement with discernable movement dynamics and an inherent movement ethos. Hirsch (2006:1990-1991) agreed: 'The Jesus movements of history can only be understood, as well as sociologically categorized, as grassroots people movements.' Some argue that the traditional institutional church has lost its movement ethos and has fallen deep into increasing institutionalism, with the result of rapid decline to such an extent that our time could be referred to as the post-Christian era (Keel 2007:139-142; Niemandt 2007:10). ${ }^{1}$ Indeed, according to Hirsch (2006:190), most major denominational churches do not exhibit an organic movement culture at all (also see Cole 2005:32; Keel 2007:43). It seems as if the church has lost its movement heart and, with it, its most fundamental calling, which is to live the way of Jesus:

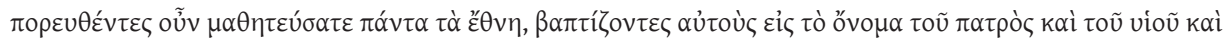

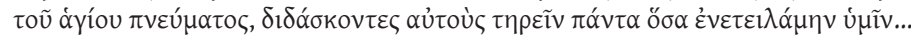

(Mt 28:19-20)

According to Campbell (2005), the crisis of the institutional church today is that it has lost the way of Jesus. Frost and Hirsch (2009:6) furthermore called on the church to go back to the Founder and to recalibrate the entire enterprise along Christological lines.

Kok (2008:35-38) argued that we are fundamentally in a crisis and disorientation situation (also see Burger 1995:14-15; Niemandt 2007:10-11) ${ }^{2}$ but, in this situation, we also find ourselves in God-space, a sacred space in which we might experience the birth and recreation of God's impossibilities that will shatter every contained view of reality (Brueggemann 1995). One of the greatest challenges to the church of the third millennium will be the (re)discovery and (re)awakening of the lost dynamics of our missional-incarnational movement ethos (Hirsch 2006:138, 187). By missional-incarnational, we mean to make manifest or comprehensible (Merriam-Webster 2003: ad loc) the nature of the Gospel message as we understand it in a way that transcends social, geographical, cultural and other boundaries, especially to those who are often geographically closest to us but socio-culturally worlds apart. We therefore have to come to understand (among other things) the fundamental dynamics and nature of social movements, for right here lies one of the most significant clues to transforming our world for Jesus (Frost \& Hirsch 2003:202). By understanding the nature of social movements, it helps us to think about the kind of situational leadership that is required, about where the strategic focus and investment of the organisation - or rather the movement - should be and about the way in which the culture of the organisation could be shaped in the dynamic direction of a new frontier.

We should essentially ask ourselves the question of where we are, here and now (Keifert 2007:16-17), with specific reference to the cycle of movements. Are we finding ourselves in the foundation period, the 


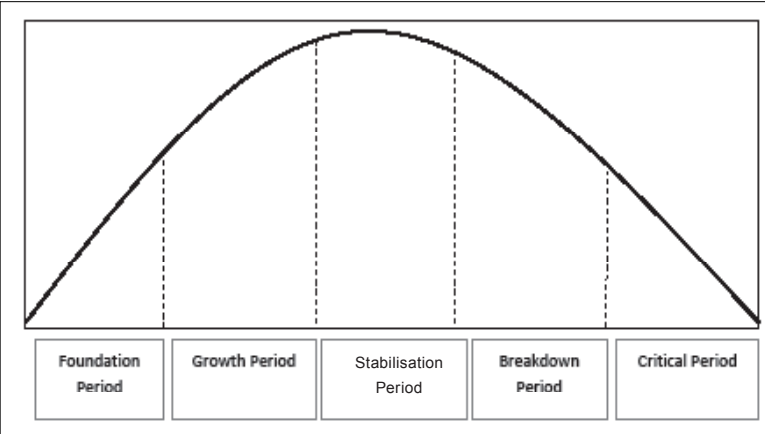

FIGURE 1

The inherent life cycle of social movements

growth period, the stabilisation period, the breakdown period or the critical period? The life cycle of movements, as developed by management studies, ${ }^{3}$ could be structured as follows:

Some argue that we are already in a crisis and disorientation situation (Burger 1995:102-104), moving towards the critical period (Hirsch 2006:195). The good news is that, in the foundation period, new life possibilities, new founding myths, new identities, new narratives and new dreams might actually be very near.

Wheatley, in Leadership and the new science, argues from the perspective of the chaos theory that chaos and disintegration give birth to new form and meaning and serve as a 'life process that releases our creative power' (Wheatley 2006:115) because '[t] he destruction created by chaos is necessary for the creation of anything new' (Wheatley 2006:119; also see Peters 1997:684). The truth of this is not only evident in the symbolic universe of the new science in the world of quantum physics and chaos theory but also fundamental to the theology of the Bible, the words of wisdom put in the mouth of Jesus by the apostle John. In John 12:24, we read the following (Campbell 2005:181):

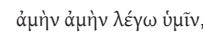

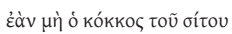

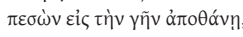

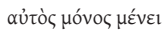

Truly I [Jesus] say unto you

Except a grain of wheat

fall into the earth and die,

it abides by itself and stays one [alone]

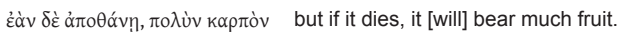

When the structure of the Greek text is closely investigated, the following dynamics of this metaphor (Van der Watt 2000) become evident:

The $\dot{\varepsilon} \alpha \dot{v}$ construction is a conditional clause in the sense that if death takes place, many fruit will be brought forth. It is clear that John wants his readers to know that death will not be the end of life but will do exactly the opposite - it will lead to life. This is also true in John 11:4, where Jesus says that the sickness of Lazarus will not end in death (although he does later die) but will bring the $\delta$ ó $\xi \alpha$ (or glory of God), which is later revealed as the restoration of Lazarus to life $(11: 25,43-44)$. In the way of Jesus, death will never be the end but the beginning of something new (Jn 5:24). Why? Because the way of Jesus is, in essence, a movement of life, restoration and transformation. It is never static but always full of vibrant vitality and life in

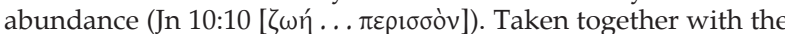
life cycle of movements, we could argue that, when the church is in either the breakdown period or the critical period (as in the radical decline in the developed world), it might be closest to a

For a discussion on the life cycle of movements based on management studies, see Hirsch (2006:192)

4.Peters (1997:68) argued that some organisms are not made to adapt beyond certain point and that, beyond that point, death is the only thing that brings new life. period of new life (as in the radical growth of Christianity in the developing world). Bell (2005:172) called this the mystery of the church: 'When she dies in one part of the world, she explodes in another'.

\section{Dynamics of social movements in the body}

If it is true that the church is in some places on the verge of the critical period, where strong tendencies of decline start to emerge (Barna 2006:29-35), the question would be how renewal movements could be activated on the one hand and, on the other hand, how deep renewal dynamics that might already be emerging could be recognised. Do we really know how to discern the characteristics of a new movement or is it only when a fullblown revival movement has already developed that we realise what has occurred? Could it be that ignorance of movements could cause the church to miss the birth of a spiritual tsunami? Snyder (1997) identified the following characteristics of typical religious movements (also see Hirsch 2006:193): A profound thirst for renewal, renewed focus on the work of the Spirit, institutional-charismatic tension, a counter-cultural concern, non-ordained, unorthodox leadership, ministry to the poor and energy and dynamism.

At first glance, we intuitively know that we have heard this before, for it sounds so familiar - and then we remember: it reminds us of the very way of Jesus, the day that he 'healed' or 'restored' the marginalised Samaritan woman, who eventually became the first missionary in John's Gospel (Barrett 1978:204).

\section{BIBLICAL PERSPECTIVE Missional-incarnational ethos}

A distinction is made between ethos and ethics. The term 'ethics' is understood as the values that we live by on the basis (motivation) of how we understand ourselves, of our relationship to God and of the world and the values, rules and principles that we infer from that. The term 'ethos' is understood as the practical way in which we live out our ethics (Lebenstil ${ }^{5}$, meaning our 'practical lifestyle') in a given socio-historical and cultural context (Van der Watt 2004:2-3). This refers to the moral vision and principles, the practices, the choices and the way of living of particular communities. As Christians, the basis or motivation for our being is built on the grounds of a particular understanding of God, of the world and of God's story for the world. In John, God loves the world (3:16), which is caught up in darkness, sin and blindness $(5: 24 ; 9: 41 ; 12: 40)$ and in which people, in essence, become the evil children of the devil (8:44). It is for this reason that God sends his only Son so that those who believe in him may have eternal life $(3: 16 ; 20: 30-31)$ and become part of a new family, the children of God (1:12). In John, soteriology entails re-socialisation and entrance into a new social reality, which serves as the basis for the formulation of the ethics of believers (Kok 2008). A fundamental dialectic relationship therefore exists between ethics and ethos. Conduct is a result of identity and therefore ethos is always a result of ethics, rooted in a particular understanding of the universal godly narrative. Ethos is, in other words, the Lebenstil or conduct of those who share a common identity. The understanding of ethics and ethos is a dynamic social process due to its realisation within a specific socio-historical context.

\section{Basis of our ethics and ethos}

Something of the reality of our world resonates with John's world-view in the sense that he recognises the reality of brokenness, destruction and disconnection of this world. In

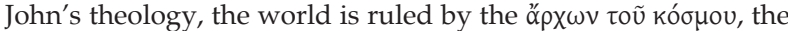
prince of this world (12:31). This prince is the father of all evil, a murderer from the beginning, one who steals and destroys and takes away life in abundance; he has been the father of destruction, lies and murder since the dawn of time (8:44). In this he is not

5.Keck (1979:13-26) understood ethos as 'Lebensteil einer Gruppe oder Gesellschaft'. 
alone, for he has many children, who embody the lifestyle of their father (8:44), who are agents of the same destruction, and, in them, no true love for God or the children of God is to be found (5:42). Most people on earth are fundamentally caught up in a life situation of crisis and disorientation, for they are spiritually dead (5:24), fundamentally lost (3:16), in desperate need of the Life that they have lost or that they never really had. They are not only spiritually dead but also spiritually sick, for they are blind $(9: 41 ; 12: 40)$, in desperate need of healing and restoration. The incarnation and mission of the Son are therefore seen against the background of this broken reality (Kok 2008).

John's view of reality corresponds with our view of reality. We do not have to look far to see the destruction when we look into the eyes of women and children who have been abused by men, to see the victims of genocide, of war, of poverty, of indescribable acts of violence against humanity, even in the destruction of Mother Earth. It is clear that we live in a reality filled with brokenness, desperately in need of healing and restoration.

John's Jesus incarnated into this world as God's agent ${ }^{6}$ to restore Life, to bring light, truth, faith, hope, restoration and reconciliation, to heal those who are spiritually blind (9:41; $12: 40)$, to restore Life in abundance (10:10) and to reveal truth (1:18). After his death and his resurrection - the culminating restorative act - he breathed over the disciples and they received the Spirit (20:22), becoming a new creation equipped to be empowered agents and called to embody the same mission as the Son (Kok 2008).

We are fundamentally called to become agents of healing and restoration in the world (Weltoffenheit), to live the way of Jesus (Gottoffenheit - Pannenberg 1976:5-13). In today's day and age, we need to regain a missional-incarnational ethos with a heart for healing and for the restoration of a world caught up in brokenness and loss of true Life. Looking through a new lens at the well-known story of the way in which Jesus restored the Samaritan woman, we may gain new insight in becoming such agents of healing and restoration.

\section{Samaritans: A story of crisis, disorientation and socio-religious brokenness ${ }^{7}$}

According to John, the Pharisees had heard that Jesus was making and baptising more followers than he was (4:1-2). Jesus knew that the Pharisees had heard about him and therefore left the unsafe Judea and went back to Galilee (4:3). On his way there, he had to go through Samaria and entered a town called Sychar, which was near the field that Jacob had given his son Joseph (4:5), and Jacob's well (4:6). Being tired and thirsty from the long, exhausting trip, Jesus sat down beside Jacob's well at about twelve o'clock noon (4:6). Jesus's disciples were not with him, for they had gone to buy food (4:8). A Samaritan woman came to the well to draw water and Jesus asked her to give him some water to drink (4:7). Surprised, the Samaritan woman

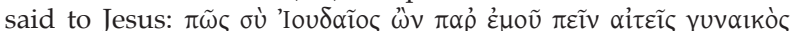

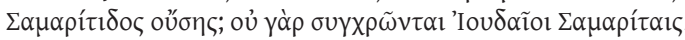

In Jesus's time, Jews never spoke to Samaritans, for, in the eyes of the Jews, they were unclean, a people judged and rejected by God, a damned nation. The deeply rooted antipathy and aversion between Jews and Samaritans goes back to the origins of the Samaritans as a mixed race, settled in the northern kingdom by the king of Assyria (2 Ki 17:24-41) (Beasley-Murray 2002:60). The crisis appeared round about $720 \mathrm{BC}$ and intensified over the centuries. Peterson (2008:20) summarised that 'Samaritans, then and now, have centuries of well-developed indifference, if not

6.For the term 'agent' as it is to be understood in John, see Borgen (1986).

7.Campbell (2005:199) also used the narrative of Jesus and the Samaritan woman as an illustration of how Jesus broke through the major religious and cultural mores of his day. outright aversion, to God-language - at least the kind used by synagogue and church people'.

The fact that Samaritans were once located in an ideal position of life possibilities within the Jewish symbolic universe (orientation) did not guarantee their positioning in the time of Jesus (Barrett 1978:194) because, in those times, they were seen as ritually impure (Brown 1966:170). Barrett rightly pointed to the fact that, from the point of view of the purity laws of the Jews, 'the daughters of the Samaritans are menstruants from their cradle (Niddah 4.1)'. All Samaritan women were viewed as unclean, as were the utensils and vessels that they held. If Jesus drank from such a vessel, he would therefore become unclean himself (Kelim passim). According to the concentric Jewish maps of persons and places, the Samaritans were seen as fundamentally out of place and cut off from God's chosen people; on the symbolic maps, they were positioned on the periphery, marginalised in the fullest sense of the word. ${ }^{8}$

It would be interesting to look at this narrative through the eyes of an ancient temple-orientated Jew. As if talking to an unclean Samaritan and drinking something that was given by a Samaritan were not enough (Barrett 1978:194; Brown 1966:170), ${ }^{9}$ Jesus talked to an unclean adulterous Samaritan woman (Aboth 1.5). This was something a true Rabbi would never do. Barclay noted the following interesting facts:

There was still another way in which Jesus was taking down the barriers: The Samaritan was a woman. The strict Rabbis forbade a Rabbi to greet a woman in public. A Rabbi might not even speak to his own wife or daughter or sister in public. There were even Pharisees who were called 'the bruised and bleeding Pharisees' because they shut their eyes when they saw a woman on the street and so walked into walls and houses! For a Rabbi to be seen speaking to a woman in public was the end of his reputation - and yet Jesus spoke to this woman. Not only was she a woman; she was also a woman of notorious character. No decent man, let alone a Rabbi, would have been seen in her company, or even exchanging a word with her - and yet Jesus spoke to her.

(2000: ad loc)

According to Keener (1993:ad loc), even the Samaritans would also have judged the woman, 'which would have resulted in ostracism from the Samaritan religious community - which would have been nearly coextensive with the whole Samaritan community'.

The crisis and disorientation life situation in this narrative therefore exists at two levels. In a sense, the (a) personal crisis and disorientation of the Samaritan woman create the opportunity of addressing the (b) larger societal crisis of marginalisation, the loss of life possibilities of Samaritans as a socio-religious group. They also create the opportunity for this narrative to act as a sign or vehicle to illustrate greater truths in John's typical way of using everyday situations to illustrate divine truths. Using this narrative, John could not have chosen a worse case scenario to illustrate the way in which Jesus gives life! It seems that John always took such worst case scenarios to illustrate this: in John 4:43-54, the boy is close to death, in John 5:1-9, the man had been sick for 38 years, in John 9:1vv., the blind man was born blind and, in John 11, Lazarus loses his life completely (Brown 1966:175-176). John's healing acts as signs of his ability to give life are therefore set against a hyperbolic background in order to accentuate and intensify Jesus's ability to give qualitative life and to restore a life situation of brokenness to a life situation of life in abundance (10:10).

8.Neyrey (1991:279) says that "[t]here are ten progressive degrees of "holiness": one moves upward and inward to the centre, from non-temple to temple, from outer courts to the Holy of Holies where God is enthroned on the cherubim. The principle of classification (and hence, of "holiness") is proximity to the heart of the temple'.

9.Brown (1966:170) remarked that '[S]amaritans were ritually impure. A Jewish regulation of A.D. 65-66 warned that one could never count on the ritual purity of Samaritan woman since they were menstruants from their cradle - see Lev xv 19.' 


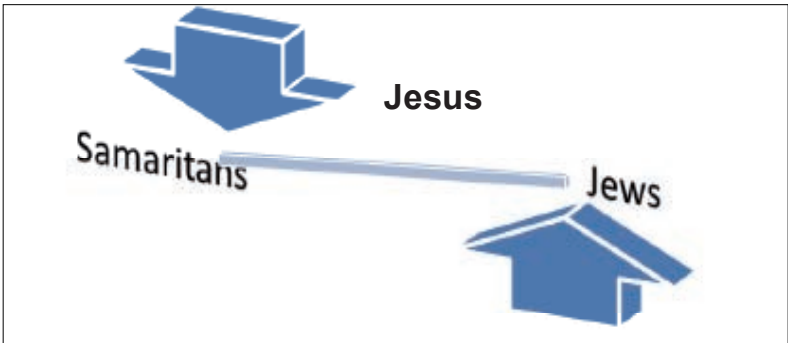

FIGURE 2

Jesus as bridge-builder

\section{Jesus as transformation agent offers the gift of Life (4:7-18)}

Through the eyes of the Jews, the Samaritans were in a marginalised socio-religious position, disconnected from the heart of the temple and therefore from the heart and presence of God. According to the Jews, the Samaritans are not part of God's chosen people and of his saving light and Life. (Ecclesiasticus 50:25 and 26 depict God as saying: 'With two nations is my soul vexed, and the third is no nation; they that sit upon the mountain of Samaria, and the Philistines, and that foolish people that dwell in Sichem.') They have lost life and are therefore a damned nation. This entails a socio-religious crisis, which results in a disorientation life situation relative to the purity maps of the Jews. In this situation of crisis and disorientation, Jesus, as transformation agent, appears right in the middle between the Jews and the marginalised Samaritans, breaking down the barriers that have separated them for many centuries. ${ }^{10}$ It is clear that a certain dynamic interaction takes place: Jesus initiates the interaction with the unclean Samaritan woman (4:7) at the well asking her for something to drink (Barrett 1978:195). In doing so, Jesus, socio-religiously speaking, moves beyond the status quo of the day (Malina \& Rohrbaugh 1992:98-99). The specific character of the social interaction that Jesus initiates has the aim or effect of creating a symbolic bridge to relate to the Samaritan woman meaningfully on a social level. Jesus therefore creates the possibility of open communication between himself and the woman, the possibility of exchanging or sharing ideas. ${ }^{11}$

The Jews built and maintained the symbolic socio-religious walls of separation and exclusivity, whereas Jesus became a bridge-builder, breaking down the barriers and particularising an incarnational way of relating to those who were marginalised and seen as outcasts, all because of his mission, his calling (Jn 3:16) [which is ultimately also our mission (Jn 20:21 - k $\alpha \theta \dot{\omega} \varsigma$

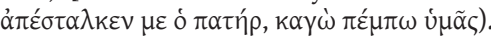

It is at this point in the movement of the narrative that Jesus shares the true spiritual reality with the Samaritan woman and offers her the gift ( $\tau \dot{\eta} v \delta \omega \rho \varepsilon \alpha \dot{v})$ ) of redeeming life $(4: 10$ - $̋ \delta \omega \rho$

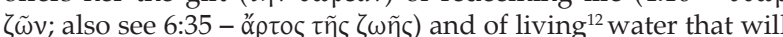

10.According to Barclay (2000:ad loc), there was also another way in which Jesus was taking down orbacle a Rabbi to greet a called 'the bruised and bleeding Pharisees' be they saw a woman on the street and so walked into walls and houses! For a Rabbi to be seen speaking to a woman in public was the end of his reputation - and ye Jesus spoke to this woman. Not only was she a woman; she was also a woman of notorious character. No decent man, let alone a Rabbi, would have been seen in her company, or even exchanging a word with her - and yet Jesus spoke to her.'

11.Malina and Rohrbaugh (1992:99) went so far as to say that, interpersonally, the woman becomes part of Jesus's in-group due to the fact that the 'public space' is transformed to 'private space' because of the sharing of utensils. This, of course, is a serious polluting act by Pharisee standards.

12. The term 'living water' is a metaphor that is not commonly used in rabbinic literature (Barrett 1978:195), although the metaphor 'water' is often used (SB II, 433-436). (Bare mor ' ater' in John is pre (6:63). This is 'water' in John is preening (6.63). This is something that only God can $d 0(4: 10,14)$. The living water that 1978:195; J 2:13; Zch 14:8; Ezk 47:9). quench all spiritual thirst (a metaphor for the spirit - Jn 7:37-39), something that only God can do.

\section{Revelation and transformational ethos}

Still the woman shows a complete lack of understanding (Barrett 1978:196) - she interprets the words of Jesus in a non-spiritual way, hears the words of Jesus through spiritual ears of unbelief. ${ }^{13}$

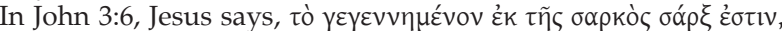

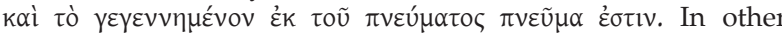
words, until one is born by the spirit, one continues to see and hear Jesus's words through spiritual eyes and ears of unbelief

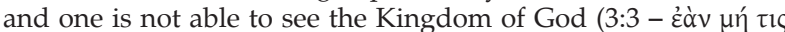

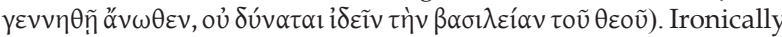
enough, the woman asks the most fundamentally important questions without realising it (Borchert 2001:204): $\pi$ ó $\theta \varepsilon v^{14}$ oũv

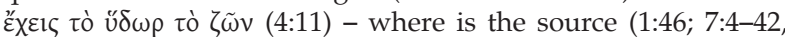
52) of living water to be found and in what way is Jesus greater than that tradition (4:12)? ${ }^{15}$ Jesus responds to these questions by

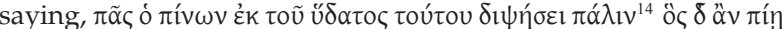

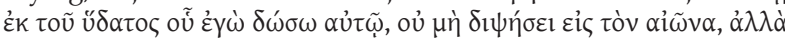

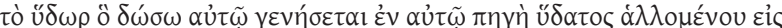

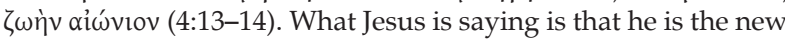
source of true life, of living water. ${ }^{16}$ For a second time, however, the woman interprets Jesus's words in a non-spiritual way, showing her lack of understanding. At this point of the social dynamics of this conversation, one might wonder whether Jesus is going to stand up and leave the woman at this point of unbelief or whether he is going to 'heal' her spiritual blindness (Jn 9:40$41 ; 12: 41$ ) by illustrating his divine origin and by performing a 'sign' in a transformation interaction. The implicit reader is left in narratological tension.

Suddenly, the level of the social interaction is transposed to the next level of abstraction - the level of revelation. Jesus utters a

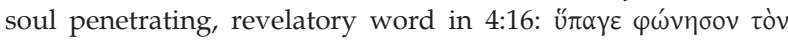

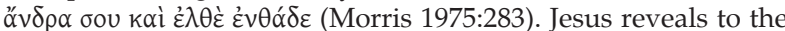
Samaritan woman that he has supernatural knowledge of her most intimate personal life, knowing of her unusually many

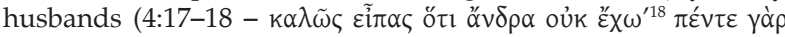

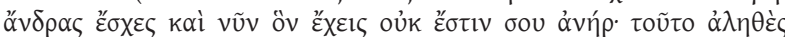

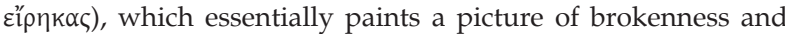
shame. This makes the interaction between Jesus and the woman even more profound: he engages meaningfully with her despite knowing of her brokenness and shame, her unclean state of being. It is clear that the Samaritan woman experiences these revelatory words as a sign $(4: 29,39)$ that Jesus is not a mere man but that he is the awaited prophet (Taheb - Dt 18:15-18) sent by God

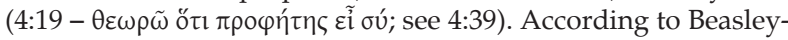
Murray (2002: ad loc), this is indeed a 'faithful reflection of the Samaritans' messianic expectation, which was defined not by the prophetic books but by the Pentateuch, notably Deut 18:1518' (Brown 1966:171). They believed that the Taheb, as another Moses, would restore true belief in God, reveal the truth and

13.In John's Gospel, salvific faith entails not only acceptance of Jesus as the Son of God but also existentially influencing and determining one's deeds (Van der Watt 2004:121). Faith in John therefore implies an implicit ethical dimension.

14. The word mó $\theta \varepsilon v$ ('whence?') is one of the key words in John, used 13 times in this gospel. According to John, most people do not know whence Jesus came (e.g. 7:27 and 8:14; a 7.27 and 8:14; also see 6:41-42). The woman did not know or understand whence Jesus recelved this living water either (4:11). It seems that at the heart of human misunderstanding about Jesus is the question of recognising his origin (Borchert 2001:204)

5.In John, Jesus becomes the new centre. He replaces or is superior to most of the cultic or historic symbols in Israel's faith. See John 6, where Jesus is said to be the bread from heaven, parallel and even greater to that which was once given by Moses. To eat the bread that is Jesus is to believe in him and have communion with him. In the same way, to drink the water is to believe. It is therefore clear that John uses the well-known traditions from Holy Scripture in arguing that Jesus is the true fulfilment of all expectations.

16. In Isaiah 55:1-5, it is promised that the thirsty (btsunf fothand hungry will receive the gift of water and bread and that outsiders will become part of the fold (Is 55:1-5). gift of water and bread and that outsiders will become part of the fold (is 55:1-5). Later, in the whom writings, this theme is taken up as a symbol for the desire of God's way of wisdom (Sir $24: 21$; 1 Enoch 48:1). un John's narrative, however, we see how Jesus offers life to the thirsty, the rejected half-breeds of Jewish society. This eventually results in one of the earliest confessions in John's Gospel (4:42). 
restore true worship of God, elements that are explicitly referred to in this particular text (MacDonald 1964:362-365). ${ }^{17}$ Morris $(1975: 266)$ remarked: 'For her to speak of Jesus as a prophet was thus to move into the area of messianic speculation.

What Jesus does is to open the woman's spiritual eyes. Suddenly, she can see something new, something unexpected, to such a degree that she later relates the coming of the Messiah with that which she experienced in her interaction with Jesus (4:25

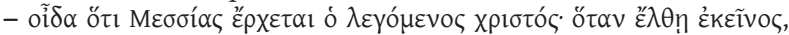

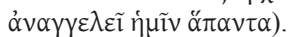

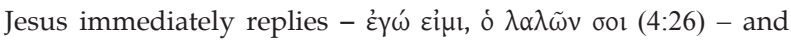
reveals his true identity to her.

\section{Multiplication/Mission/Invitational Ethos}

In the next scene, the narrator introduces the disciples (4:27), almost interrupting the conversation. The woman energetically leaves the scene and goes into the city (4:28), where she gives

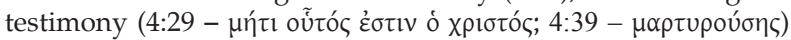
of the transformational interaction that she has experienced $(4: 28,39)$, this in a world where women never do such things, especially women with a notorious character. The result of this testimony is that this not only is a sign to the Samaritan woman but also becomes a personal testimony that eventually convinces others of Jesus's true identity ${ }^{18}$ (4:39; Culpepper 1983:91; Morris 1975:283). The Samaritan woman first sees a Jew, then a prophet and, finally, the Messiah (Wengst 2000:172). In this narrative, there are, in other words, progressive degrees of development to the extent that they culminate in a true Johannine confession, becoming a witness to Jesus's true identity - the first missionary to the Samaritans, spreading the good news of the Christ's coming to the world. Wengst (2000:184) was therefore correct in postulating that 'Das Zeugis der Frau weckt also Glauben, und es entsteht Gemeinde als neue Sozialität'. This is seen in 4:39:

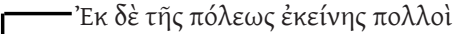

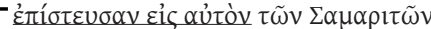

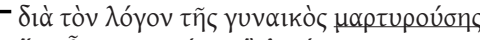

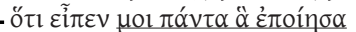

It is clear that the Samaritans come to faith in Jesus ( $\pi 0 \lambda \lambda$ oi

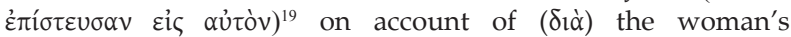

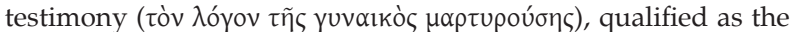
transformational interaction that she experienced with Jesus, who revealed truth in her life (Culpepper 1993:91; Wengst 2000:184), something that the Taheb does (Macdonald 1964). ${ }^{20}$ The faith of this woman reminds the reader of salvific faith. ${ }^{21}$ In John's Gospel, salvific faith (pisteo and its 98 occurrences) not only entails acceptance of Jesus as the Son of God but also existentially influences and determines one's deeds (Van der Watt 2004:121). The woman and the Samaritans (4:42) eventually come to true faith in the source of living water. In John, those who believe become reborn children of God and receive the right ( $\dot{\xi} \xi o v \sigma i ́ \alpha v$, in 1:12) to be called God's children (1:12).

Jesus's interaction with the Samaritan woman eventually develops into a magnificent transformational interaction,

\section{Thyen $2005: 256$}

18.Campbell (2005:200): 'The woman was transfixed by her encounter with Jesus, and she ran to tell anyone who'd listen. So much was she a dramatically changed woman that the people of Sychar were drawn into the message of Jesus.

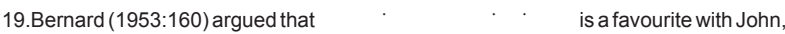
occurring no less than six times in this Gospel $(7: 31 ; 8: 30 ; 10: 42 ; 11: 45 ; 12: 42)$. He postulated that ' $[$ t]he aorist seems to indicate a definite, but not necessarily lasting, movement of faith evoked by special words or deeds of Jesus'.

20.According to Thyen (2005:282), the faith of the Samaritans is only provisional ('verläufiger').

21.According to Barclay (2000:172), the Samaritan woman is a great example of his saving power. He argued that the town where she stayed would no doubt have saving power. He argued that the town where she stayed would no doubt have her; he enabled her to break away from the past and he opened up a new future her; he leading to spiritual reorientation and a representation of reality and to the dynamic energy associated with a missionary impulse (Hirsch 2006:193-194). Suddenly, everything changes for the Samaritan woman: she is transformed from an unclean, marginalised Samaritan woman to a faithful witness, someone whose brokenness is radically restored. Even her eschatological life possibilities change (Wengst 2000:180-181). ${ }^{22}$ According to John 5:24, those who hear his word and believe him who sent Jesus already have eternal life and do not come into judgement because they have already passed from death to life.

Later, in their interaction with Jesus, even more Samaritan people experience Jesus's words and confess that they also

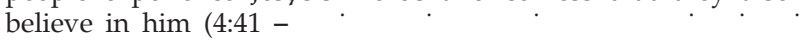
$[-\dot{K} \in \mathbb{K} n \mathbb{N}$ à). The only difference is that they now do not believe in him because of the woman's testimony alone but also because

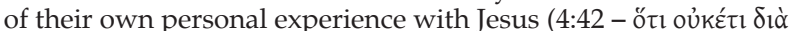

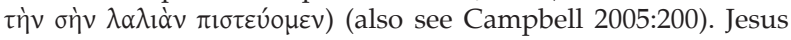
touches their personal lives to such an extent that their spiritual eyes and ears are opened (Bernard 1953:160) and they see and

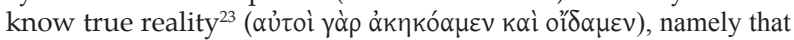

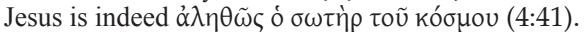

In his discussion of the dynamics of movements, Hirsch (2006:194) remarked that 'new missional movements almost always begin on the edges of society/culture and among the common people. They are nonelitist. And they have the ability to excite and enlist others as leaders and participants'. This is in synchronisation with those scholars who argue that the main stimulus for the renewal of Christianity more often than not comes from the bottom and from the edge, from exactly those sectors of the Christian world that are on the margins of society (Hirsch 2006:194). In the narrative of Jesus and the Samaritan woman, it becomes clear that the unclean, marginalised Samaritan woman becomes the first missionary to the unclean, common Samaritans and that the stimulus for this renewal comes from the bottom and from the edge, from the margins of society. ${ }^{24}$

From the investigation above, it becomes clear that it is Jesus's missional-incarnational ethos that culminates not only in the reality of transformation and restoration but also in the activation of the dynamics of a movement. In other words, Jesus's presence gives birth to a spiritual movement and to lives that are transformed, leading to transformed and restored people who move and invite others to join them. A missionalincarnational spirituality and ethos result in the bringing of the presence of Christ into marginalised places or spaces where such presence is not recognised. This leads to revelation (when people's spiritual eyes are opened) and restoration, which then leads to a dynamic missional movement when people share the transformational wonder that they experience and invite others to participate. Plainly said: Jesus's presence reaches out, builds bridges, invites, restores, heals, transforms and moves people to missional action. This is as close to the dynamics of a movement ethos as one can get!

The building of a vibrant community life where real sharing, mutuality, justice, service and solidarity take place is therefore of

22. Wengst (2000:180-181) remarked that 'In der Gemeinde fanden Menschen neue Lebensmöglichkeiten, deren bedrücktes Leben perspektivlos erschien, die durch Lebensbrüche hindurchgegangen waren. Sie fanden in geteilten Leben in der Gemeinde erfilltes Leben:

23.Bernard (1953:161) argued that the initial stages of belief may be brought about by the testimony of others but the belief in Jesus that is complete and assured is realised in the context of personal contact and association with the living Christ. This passage is rightly referred to as the mission to the Samaritans.

24.Jesus's interaction with the Samaritan woman could be interpreted within the framework of a restorative hermeneutic of representation. In John, God has moved from the localised materialistic to the 'glocal' ('global and local') spiritualistic. 'Glocal' means that God is localised wherever Jesus is but 'globalistic' means that 'Glocal' means that God is localised wherever Jesus is but 'globalistic' means that Jesus is found not only with the Jews but also with the Samaritans $(4: 1-42)$ and even with the gentiles (4:43-54). Wherever Jesus is the Father is and the life that the Father offers becomes apparent. In this narrative, it is clear that not only is the broken relationship between the Samaritan woman and God restored but also that there is a potential restoration of the broken relationship between Samaritans and Jews. This narrative represents reality to such an extent that reconciliation between Jew and Samaritan becomes possible. 
the church's essence and is a sign and foretaste of both its own destiny and that of all creation.

(Bevans \& Schroeder 2004:298)

Jesus's mission is fundamentally also our mission, as Jesus

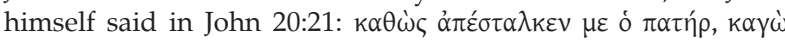
$\pi \varepsilon ́ \mu \pi \omega \dot{v} \mu \tilde{\alpha} \varsigma$ ('As the Father has sent me I also send you ...'). Jesus's missional activity originated in God's mission but the dynamics of that movement continues in the missional-incarnational ethos of the church, the organic, vibrant, living body of Christ:

At its very heart, Christianity is therefore a messianic movement, one that seeks to consistently embody the life, spirituality, and mission of its Founder. We have made it so many other things, but this is its utter simplicity. Discipleship, becoming like Jesus our Lord and Founder, lies at the epicenter of the church's task. It means that Christology must define all that we do and say. It also means that in order to recover the ethos of authentic Christianity, we need to refocus our attention back to the Root of it all, to recalibrate ourselves and our organizations around the person and work of Jesus the Lord. It will mean taking the Gospels seriously as the primary texts that define us. It will mean acting like Jesus in relation to people outside of the faith.

(Hirsch 2006:94)

\section{CONCLUDING REMARKS}

\section{The challenge of the Church today: Ecclesiology,} spirituality, leadership

The challenge of the church today, in its attempt to activate the dynamics of movement, exists at three levels: ecclesiological, spiritual and leadership (Frost \& Hirsch 2003; also see Keel 2007:25).

Ecclesiologically, we have to be incarnational instead of attractional: Jesus's incarnational ethos results in the bringing of the presence of God into marginalised places or spaces where such presence is usually believed not to be found. Hirsch (2006:133) called it the relative anonymity of incarnational ways of engaging in mission. Jews fled from the space where Jesus had interaction with the Samaritan woman; Jesus, however, reached out to the unclean, marginalised Samaritan woman in an incarnational way, bringing the reality and presence of living water, the sphere of light into a space that was seen as dark and unclean by the religious establishment of the day. To be incarnational, we have to cross boundaries, break down social-constructionistic symbolic fences and barriers, and build bridges that create the possibility of open communication and interaction. Such a church is missional by intent, where daily life is seen as an expression of the sent-ness by God into this world (Frost 2006:151). We have to plant the seeds of the Kingdom of God in places where life happens and where society is formed (Cole 2005:xxvi). A missional-incarnational ecclesiology more often than not leads to being church in the world, mostly in marginalised, unsafe, untamed spaces.

Spiritually: From dualistic to holistic: Jesus illustrates that his spirituality is not dualistic but holistic - all space is God's space. He illustrates that God's Kavod (presence and weight) is present not only in the so-called holy spaces but also in the so-called unholy spaces, in the midst of the lame (Jn 5:1-9), the blind (Jn 9), the lepers (Mk 1:40-45), the sinners and the outcasts (Mk 15:1). As the church, we should realise that the whole world is God's world, that there should be no distinction between secular and sacred, between those who are ordained and called for special duty and those believers who are not. All God's children, in every sphere of life - in music, art, business etc. - are called, not only the clergy. We should furthermore realise that secular work is also sacred (Niemandt 2007:72-73), that we should integrate the sacred and the secular where the everyday is redeemed (Frost 2006:186)

Our leadership thinking has to move from being hierarchical to being egalitarian: In Jewish thought, the map of persons and places corresponded: holy people were found in holy places and unholy people were found in unholy places and kept far from so-called holy spaces (Neyrey 1991). The Jews had an established hierarchical leadership structure that was inherently embedded in a societas structure (Burger 1995:28). The Jesus movement, however, was, in essence, an egalitarian communitas structure. Here, we are called to serve one another in love, following the way of Jesus (Frost 2006:111-115) (Jn 13:1-17). Jesus recruited the common fishermen of his day, those who, according to Bell (2005:132), did not make the cut, mostly those who were on the margins of society - those whose being he radically restored. Hirsch (2006:167) called this leadership and followership based on common and shared meaning and purpose, where the work is described and not prescribed (Cole 2005:134). It is a flat structure, with authority distributed to each participant in God's mission (Cole 2005:135).

Let us therefore remind ourselves that the main stimulus for the renewal of Christianity, that the dynamics of movements, more often than not comes from the bottom and from the edge, from exactly those sectors of the Christian world that are on the margins of society (Bell 2005:132; Hirsch 2006:194). Let us (re)discover our missional-incarnational ethos by living the way of Jesus and let us become highly responsive to the deep spiritual thirst in the world (Hirsch 2006:197-198). The way of Jesus fundamentally calls us to become missional-incarnational agents of healing and restoration, bringing light where there is darkness, life where there is death, meaning where all meaning is lost, hope where there is no hope (Campbell 2005:183). In the process, this might illustrate something of God's impossibilities that will shatter every contained view of reality (Brueggemann 1995:xvii), leaving room for the passion for the possible and the paradigm of wonder, reminding us that all social change starts with the construction of alternative stories of what might indeed become possible - an alternative reality filled with hope, expectation and possibility (Ezk 37:1-14; Is 44:3-4). It is often in the context of loss, brokenness, crisis and disorientation that the need for alternative narratives is born and in which we can make a radical missional and restorative impact in the world, for the Gospel is, in essence, a message of healing, restoration and reconciliation (Mt 10; Lk 7:22; also see Jn 12:40; Jr 6:10 etc.; also see Kok 2008). Against the background of brokenness, the world, as we know it, is desperately in need of healing, restoration and reconciliation, calling the church to embark on a missionalincarnational journey of healing, restoration and reconciliation.

\section{REFERENCES}

Barclay, W., [c. 1975] 2000, The Gospel of John: volume 1. The daily study Bible series, rev. edn., Westminster Press, Philadelphia.

Barna, G., 2006, Revolution. Finding vibrant faith beyond the walls of the sanctuary, CAP, Vereeniging.

Barrett, C.K., 1978, The Gospel according to St. John, 2nd edn., Westminster Press, Philadelphia.

Bash, H., 1995, Social problems E social movements: An exploration into the sociological construction of alternative realities, Humanities Press, Atlantic Highlands.

Beasley-Murray, G.R., 2002, John. Word biblical commentary, Word, Incorporated, Dallas.

Bell, R., 2005, Velvet Elvis. Repainting the Christian faith, Zondervan, Grand Rapids.

Bernard, J.H., 1953, A critical and exegetical commentary on the Gospel according to St. John, vol. 1, Clark, Edinburgh.

Bevans, S.B. \& Schroeder, R.P., 2004, Constants in context. A theology of mission for today, Orbis, New York.

Borchert, G.L., [c. 1996] 2001, John 1-11, (vol 25a), The New American Commentary, Broadman \& Holman Publishers, Nashville.

Borgen, P., 1986, 'God's agent in the fourth Gospel', in J. Ashton (ed.), The Interpretation of John, pp. 67-78, SPCK, London.

Bosch, D., 1991, Transforming mission: Paradigm shifts in the theology of mission, Orbis, Maryknoll. 
Brown, R.E., 1966, The Gospel according to John, vol. 1, Doubleday, New York.

Brown, R.E., 1970, The Gospel according to John, vol. 2, Doubleday, New York.

Brueggemann, W., 1995, The Psalms and the life of faith, Fortress Press, Minneapolis.

Burger, C.W., 1995, Gemeentes in transito. BUVTON, Lux Verbi, Kaapstad.

Campbell, J., 2005, The way of Jesus, Jossey Bass, San Francisco.

Cole, N., 2005, Organic church. Growing faith where life happens, Jossey Bass, San Francisco.

Culpepper, R.A., 1983, Anatomy of the fourth Gospel: A study in literary design, Fortress Press, Philadelphia.

Culpepper, R.A., 1993, 'John 5:1-18: A sample of narrative critical commentary', in M.W.G. Stibbe (ed.), The Gospel of John as literature: An anthology of twentieth-century perspectives, pp. 193-207, Brill, Leiden.

Frost, M. \& Hirsch, A., 2003, The shaping of things to come. Innovation and mission for the 21st century church, Hendrickson, Peabody.

Frost, M. \& Hirsch, A., 2009, ReJesus: A wild Messiah for a missional church, Hendrickson, Peabody.

Frost, M., 2006, Exiles: Living missionally in a post-Christian culture, Hendrickson, Peabody.

Gibbs, E. \& Coffey, I., 2001, Church next. Quantum changes in Christian ministry, IVP, Downers Grove.

Hirsch, A., 2006, The forgotten ways, Brazos, Grand Rapids.

Keel, T., 2007, Intuitive leadership. Embracing a paradigm of narrative, metaphor $\mathcal{E}$ chaos, Baker, Grand Rapids.

Keener, C.S., 1993, The IVP Bible background commentary: New Testament, InterVarsity Press, Downers Grove.

Keifert, P., 2007, Ons is nou hier. 'n Nuwe era van gestuur wees, Allelon, Idaho.

Kok, J., 2008, 'Siekte en gebrokenheid teenoor genesing en restourasie in Johannes', PhD-proefskrif, Universiteit van Pretoria.
Kok, J., 2009, 'Die opstanding as die kulminerende genesingshandeling van God in Johannes', Verbum et Ecclesia 30(1), 112-147.

MacDonald, J., 1964, The theology of the Samaritans, SCM, London.

Malina, B.J. \& Rohrbaugh, R.L., 1992, Social-science commentary on the synoptic Gospels, Fortress Press, Minneapolis.

Merriam-Webster, I., 2003, Merriam-Webster's collegiate dictionary, includes index, 11th edn., Merriam-Webster, Inc., Springfield.

Morris, L., 1975, The Gospel according to John, Eerdmans, Grand Rapids.

Neyrey, E., 1991, The social world of Luke-Acts. Models for interpretation, pp. 361-387, Hendrikson, Peabody.

Niemandt, N., 2007, Nuwe drome vir nuwe werklikhede, Lux Verbi, Wellington.

Pannenberg, W., 1976, Was ist der Mensch? Die Anthropologie der Gegenwart im Lichte der Theologie, Vandenhoeck, Göttingen.

Peters, T., 1997, The circle of innovation. You can't shrink your way to greatness, Hodder\&Stoughton, London.

Peterson, E.H., 2008, Tell it slant. A conversation on the language of Jesus in his stories and prayers, Eerdmans, Grand Rapids.

Snyder, H.A., 1997, Signs of the Spirit. How God reshapes the church, Zondervan, Grand Rapids.

Thyen, H., 2005, Das Johannesevangelium, Mohr Siebeck, Tübingen.

Van der Watt, J.G., 2000, Family of the king. Dynamics of metaphor in the Gospel according to John, Brill, Leiden.

Van der Watt, J.G., 2004, 'Directives for the ethics and ethos research project', University of Pretoria, Pretoria.

Van der Watt, J.G. \& Kok, J., 2008, 'Geweld in 'n evangelie van liefde' (1 \& 2), Hervormde Teologiese Studies 64(4), 1793-1812.

Wengst, K., 2000, Das Johannesevangelium, 1. Teilband: Kapital 1-10, Kohlhammer, Stuttgart.

Wheatley, M., 2006, Leadership and the new science, Berrett Koehler, San Francisco. 